\title{
Matricaria Recutita Extract (Chamomile) to reduce Candida Albicans and Entrobacter Cloacae biofilms: in vitro study
}

\author{
Extrato de Matricaria recutita (camomila) para redução do biofilme de Candida albicans e Entrobacter \\ cloacae: estudo in vitro
}

\author{
Maitê Alves PEQUENO ${ }^{1}$ \\ (iD) ORCID ID 0000-0003-3962-1720 \\ Marissa Rodrigues SILVESTRE ${ }^{1}$ \\ (iD) ORCID iD 0000-0001-6755-0267 \\ Isabela AMÊNDOLA² \\ (D) ORCID iD 0000-0002-0010-9757 \\ Célia Regina Gonçalves e SILVA² \\ (D) ORCID iD 0000-0002-6581-6612 \\ Mariella Vieira Pereira LEÃO2 \\ (iD) ORCID iD 0000-0003-1949-3207 \\ Silvana Soleo Ferreira dos SANTOS² \\ (iD) ORCID iD 0000-0001-5827-7721
}

\section{ABSTRACT}

\section{Objective}

This research study aimed at evaluating the inhibitory activity of Matricaria recutira (chamomile) hydroalcoholic extract on Candida albicans and Enterobacter cloacae biofilms.

\section{Methods}

C. albicans and E. cloacae biofilms with thirty-hour formation were submitted, for five minutes, to 100,200 and $300 \mathrm{mg} / \mathrm{mL}$ of M. recutita hydroalcoholic extract, chlorhexidine digluconate $0.12 \%$ (Periogard ${ }^{\circledR}$ - inhibition control) or sterile distilled water (growth control). Subsequently, they were washed and divided into two groups to determine the microbial viability: G/UFC - counting of colony forming units (cfu) in agar and G/DNA - quantification of viable DNA with violet crystal dye by spectrophotometry.

\section{Results}

M. recutita extract at $300 \mathrm{mg} / \mathrm{mL}$ reduced significantly $(p<0.01)$ the $\mathrm{E}$. cloacae $c f u / \mathrm{mL}$ number in biofilm with results similar to chlorhexidine $0.12 \%$, while extracts at 100 and $200 \mathrm{mg} / \mathrm{mL}$ did not have the same effectiveness. The amount of E. cloacae viable DNA was reduced ( $p<0.05)$ in all the M. recutita extract concentrations and chlorhexidine. There was no significant difference $(p=0.565)$ in the cfulmL number or in the amount of viable DNA ( $p=0.8094)$ in C. albicans biofilm when compared to untreated biofilm (control) or, even, between the extracts when compared to each other or to chlorhexidine $0.12 \%$.

\section{Conclusion}

$300 \mathrm{mg} / \mathrm{mL}$ M. recutita extract reduced significantly the E. cloacae biofilm but not the $\mathrm{C}$. albicans, both with a similar result to chlorhexidine $0.12 \%\left(\right.$ Periogar $\left.{ }^{\circledR}\right)$.

Indexing terms: Biofilms. Candida Albicans. Enterobacter Cloacae. Matricaria. Phytotherapy.

\section{RESUMO}

\section{Objetivo}

Avaliar a atividade inibitória do extrato hidroalcoólico de Matricaria recutira (camomila) sobre biofilme de Candida albicans e Enterobacter cloacae.

\section{Métodos}

Biofilmes de C. albicans e E. cloacae com trinta horas de formação foram submetidos por cinco minutos a 100, 200 e $300 \mathrm{mg} / \mathrm{mL}$ de extrato hidroalcoólico de $M$. recutita, digluconato de clorexidina $0,12 \%$ (Periogard ${ }^{\circledR}$ - controle de inibição) ou água destilada esterilizada (controle do crescimento). Depois foram lavados e divididos em dois grupos para determinação da viabilidade microbiana: G1 - contagem de unidades formadoras de colônia (ufc) em ágar e G2 - quantificação de DNA viável com corante cristal violeta por espectrofotometria.

\section{Resultados}

O extrato de $M$. recutita a $300 \mathrm{mg} / \mathrm{mL}$ reduziu significativamente $(\mathrm{p}<0,01)$ o número de $\mathrm{ffc} / \mathrm{mL}$ de $E$. cloacae em biofilme com resultados semelhantes a clorexidina $0,12 \%$, enquanto os extratos a 100 e $200 \mathrm{mg} / \mathrm{mL}$ não tiveram a mesma efetividade. Já a quantidade de DNA viável de $E$. cloacae foi reduzida $(p<0,05)$ em todas as concentrações do extrato de $M$. recutita testadas e clorexidina. Não houve diferença significativa $(p=0,565)$ no número de ufc/mL ou na quantidade de DNA viável $(p=0,8094)$ no biofilme de $C$. albicans quando comparado ao biofilme sem tratamento (controle) ou mesmo entre as concentrações do extrato quando comparados entre si ou com a clorexidina $0,12 \%$.

\section{Conclusão}

O extrato de $M$. recutita $300 \mathrm{mg} / \mathrm{mL}$ reduziu significativamente o biofilme de E. cloacae mas não de $C$. albicans, ambos com resultado semelhante à clorexidina 0,12\% (Periogar®).

Termos de indexação: Biofilme. Candida albicans. Enterobacter cloacae. Matricaria. Fitoterapia.

${ }^{1}$ Universidade de Taubaté, Faculdade de Odontologia. Av. Tiradentes, 500, 12030-180, Centro, Taubaté, SP, Brasil. Correspondência para / Correspondence to: MA PEQUENO. E-mail: <maite.peq@Hotmail.com>.

${ }^{2}$ Universidade de Taubaté, Instituto básico de Biociências. Taubaté, SP, Brasil.

$\boldsymbol{\nabla} \mathbf{\nabla} \boldsymbol{\nabla}$

Como citar este artigo / How to cite this article

Pequeno MA, Silvestre MR, Amêndola I, Silva CRG, Leão MVP, Santos SSF. Matricaria Recutita Extract (Chamomile) to Reduce Candida Albicans and Entrobacter Cloacae Biofilms: in vitro study. RGO, Rev Gaúch Odontol. 2018;66(2):00-00. http://dx.doi.org/10.1590/1981-863720180002000033328 


\section{INTRODUCTION}

Among the microorganisms capable of biofilm formation, causing oral diseases in predisposing conditions, are the yeasts of the genus Candida, mainly the $C$. albicans and the enteric gram-negative bacilli such as the E. cloacae.

C. albicans is a member of the normal human microbiota and colonizes the oral cavity, the gastrointestinal tract and the genitourinary tract of $70 \%$, or more, of the population [1], as a commensal agent, but, inducing infection. In the mouth, it occurs when there is an alteration in such environment or immunological dysfunction conditions [2]. The ability of this species to transition from a commensal to a pathogenic agent is related to a repertoire of virulence factors, such as adhesion capacity to the mucosa, epithelium and artificial materials, including medical and dental devices (catheters, probes, pacemakers etc.), dimorphism with the production of filamentous structures causing tissue invasion, significant thermotolerance and production of enzymes such as proteinases and phospholipases [3-5]. This enzyme, located on the surface of the yeast and at the end of the germ tube, acts on the phospholipids hydrolysis and causes damage to the epithelial cell [6].

The Enterobacter is a gram-negative common genus, facultative anaerobic, bat-shaped bacteria belonging to the Enterobacteriaceae family. The E. cloacae species has clinical significance as an opportunistic bacteria and is a hospital pathogen in intensive care patients [7]. Resistance to $\beta$-lactam and extended-spectrum $\beta$-lactam (ESBL) often complicates the treatment of $E$. cloacae related infections [8]. This species is not considered to be part of the oral cavity, however, it was the most commonly isolated species among the facultative anaerobic gramnegative microorganisms in adult subjects, presenting chronic periodontitis [9] and in tongue backs of men and women between 30-50 years of age [10].

In addition to the mechanical control, the biofilm chemical control is recommended as well; however, some substances can generate side effects such as tooth staining, taste alterations, soft tissue burns, pain, xerostomia, scaly lesions, ulcerations and unpleasant taste in the mouth [11].

As an alternative for biofilm control, studies conducted with herbal medicine have demonstrated its applicability in clinical practice, mainly to treat and prevent less severe conditions [12]. The use of this resource to treat the population has been one of the goals of the Brazilian Ministry of Health, especially to treat those whose socioeconomic conditions are unfavorable to buy manufactured drugs. This initiative is based on the National Policy on Integrative and Complementary Practices at SUS, approved by the National Health Council in 2005 and published by Decree GM No. 971, dated May 3,2006 , proposing the inclusion of medicinal plants and phytotherapy as a therapeutic option in the public health system [13].

In Dentistry, researches with natural products have increased in recent years, because besides presenting a more affordable cost to the population, their acceptance leads to good prospects in dental market products containing natural substances [14].

Matricaria recutita also known as chamomile can be an alternative for use in Dentistry. Plants from the Asteraceae family, from European origin, grows in mild climates, but can adapt to warmer climates. It has an intense and sweet aroma, presenting anxiolytic, digestive and sedative properties, but, in Dentistry, the properties that stand out are its antiseptic and anti-inflammatory properties [15].

Therefore, the goal of this research study was to evaluate the inhibitory activity of the $M$. recutita hydroalcoholic extract on C. albicans and E. cloacae biofilms to contribute to the use of this phytotherapic agent in Dentistry.

\section{METHODS}

Considering the in vitro tests, C. albicans (ATCC 18804) and E. cloacae (CCUT 01003) strains from the cultures collection of the University of Taubaté were used in this research study.

The minimum inhibitory concentration (MIC) of the $M$. recutita hydroalcoholic extract (Farmaway, Taubaté, São Paulo, Brazil) on strains in the planktonic phase was determined by the broth microdilution method [16]. In order to verify the extract action on the biofilm, the MIC was used for the planktonic phase and higher concentrations, until reaching the extract maximum concentration (300 $\mathrm{mg} / \mathrm{mL}$ )

For the biofilm formation, each strain was seeded in brain heart infusion broth $(\mathrm{BHI}$, Kasvi, Roseto degli Abruzzi, Italy) and incubated at $37^{\circ} \mathrm{C}$ for 24 hours, centrifuged (Centribio TDL80-2B centrifuge, Shanghai, 
China) at $3700 \mathrm{rpm}$ for ten minutes and the supernatant discarded. The deposit was resuspended in sterile saline $(\mathrm{NaCl}$ 0.9\%), centrifuged and the supernatant discarded. This procedure was repeated three times for waste removal from the culture medium. From the reservoir, C. albicans and $E$. cloacae suspensions were prepared in sterile saline solution, adjusted at 106 and 108 cels $/ \mathrm{mL}$, respectively, in a spectrophotometer (Femto 432C, São Paulo, Brazil wavelength: 530 and $590 \mathrm{~nm}$, respectively).

In 96 well microdilution plates (SPL Life Sciences, Gyeonggi-do, Korea), $200 \mu \mathrm{L}$ of the C. albicans or E. cloacae suspension were added, incubated at $37^{\circ} \mathrm{C}$ under agitation (75 rpm, Biomixer TS multifunctional stirrer -2000, China) for 90 minutes for initial adhesion. Then, the culture medium was removed and each well was washed three times with sterile saline to remove unbound cells. $200 \mu \mathrm{L}$ of $\mathrm{BHI}$ broth was added to the washed wells, incubated at $37^{\circ} \mathrm{C}$ for 24 hours and, then, the culture medium was removed and each well washed three times with sterile saline to remove unbound cells.

Twelve repetitions were performed for each group (Table 1) at two different times, totaling 24 repetitions for each group (Chart 1).

Table 1. Optical densities for Candida albicans cell viability test in untreated (control) biofilm and treated with Matricaria recutita extract $(83,100,200$ and $300 \mathrm{mg} / \mathrm{mL}$ ) and chlorhexidine $0.12 \%$.

\begin{tabular}{llllll}
\hline $\begin{array}{l}\text { Matricaria recutita extract } \\
\mathbf{m L})\end{array}$ & $\mathbf{m g} /$ & $\begin{array}{l}\text { Chlorhexidine } \\
\mathbf{0 . 1 2} \%\end{array}$ & Control \\
$\mathbf{8 3}$ & $\mathbf{1 0 0}$ & $\mathbf{2 0 0}$ & $\mathbf{3 0 0}$ & & \\
\hline 0.142 & 0.128 & 0.145 & 0.151 & 0.130 & 0.148 \\
0.142 & 0.092 & 0.124 & 0.13 & 0.177 & 0.139 \\
0.085 & 0.104 & 0.148 & 0.123 & 0.077 & 0.294 \\
0.142 & 0.215 & 0.193 & 0.179 & 0.143 & 0.104 \\
0.083 & 0.152 & 0.162 & 0.142 & 0.246 & 0.129 \\
0.065 & 0.097 & 0.104 & 0.118 & 0.092 & 0.093 \\
0.054 & 0.050 & 0.100 & 0.105 & 0.059 & 0.096 \\
0.067 & 0.064 & 0.114 & 0.104 & 0.057 & 0.097 \\
0.123 & 0.076 & 0.071 & 0.155 & 0.077 & 0.094 \\
0.182 & 0.093 & 0.062 & 0.170 & 0.139 & 0.151 \\
0.143 & 0.137 & 0.117 & 0.107 & 0.107 & 0.143 \\
0.156 & 0.140 & 0.113 & 0.144 & 0.189 & 0.078 \\
\hline
\end{tabular}

Anova, $\mathrm{gl}=5, \mathrm{p}=0.8094$
Chart 1. Microorganisms, groups and treatments used in biofilm assays, wherein: $\left(^{*}\right)$ Sodium Chloride $(\mathrm{NaCl}) 0.9 \%$ and $\left({ }^{* *}\right)$ Periogard $\circledast$, Colgate-Palmolive Company, Brazil.

\begin{tabular}{lll}
\hline Microorganism & Gr & Treatment \\
\hline & 1 & Sterilized saline solution (positive control) * \\
& 2 & Chlorhexidine $0.12 \%$ (negative control) ** \\
Candida & 3 & M. recutita extract $83 \mathrm{mg} / \mathrm{mL}(\mathrm{MIC})$ \\
albicans & 4 & M. recutita extract $100 \mathrm{mg} / \mathrm{mL}$ \\
& 5 & M. recutita extract $200 \mathrm{mg} / \mathrm{mL}$ \\
& 6 & M. recutita extract $300 \mathrm{mg} / \mathrm{mL}$ \\
Enterobacter & 7 & Sterilized saline solution $(\mathrm{positive} \mathrm{control)} \mathrm{*}$ \\
cloacae & 8 & Chlorhexidine $0.12 \%(\mathrm{negative} \mathrm{control)} \mathrm{**}$ \\
& 10 & M. recutita extract $100 \mathrm{mg} / \mathrm{mL}(\mathrm{MIC})$ \\
& 11 & M. recutita extract $200 \mathrm{mg} / \mathrm{mL}$ \\
& &
\end{tabular}

For the biofilm treatment, $200 \mu \mathrm{L}$ of $M$. recutita hydroalcoholic extract were added to the wells with different concentrations or control solutions (sterile saline solution or chlorhexidine $0.12 \%$ ), as shown in Table 1 , where they remained for five minutes. Then, they were removed and the biofilm washed three times with sterile saline, as described above, for extract removal or control solution.

After washing, twelve wells from each group received $200 \mu \mathrm{L}$ of sterile saline solution and the biofilm cells were detached by friction with a sterile tip. From the detached cell suspension, multiple serial dilution of two (10 ${ }^{2}$ to $10^{-8}$ ) and plated (G / CFU) were performed by the drop technique [17] on BHI agar (Kasvi, Roseto degli Abruzzi, Italy). The media were incubated for 24 hours at $37^{\circ} \mathrm{C}$ and the reading performed by counting and calculation of the colony forming units per milliliter (cfu/ml). The $\mathrm{cfu} / \mathrm{ml}$ numbers were transformed into base 10 logarithms.

For the cell viability test (G/DNA), $100 \mu \mathrm{L}$ of formaldehyde 10\% (Chemco, Hortolândia, São Paulo, Brazil) were added to each one of the twelve remaining wells in each group, being removed after ten minutes (fixation). The wells were washed with $200 \mu \mathrm{L}$ of sterile saline and then $100 \mu \mathrm{L}$ of violet crystal dye were added (Dynamics, Brazil, $0.2 \mathrm{mg} / \mathrm{mL}$ sterile distilled water concentration). The plate was covered with foil and incubated at $37^{\circ} \mathrm{C}$ under agitation for 15 minutes ( $75 \mathrm{rpm}$ - TS-2000A Multifunctional Shaker). After discarding the supernatant, each well was washed with $200 \mu \mathrm{L}$ of distilled water and then $100 \mu \mathrm{L}$ of $95 \%$ ethyl alcohol were added (Synth, Labsynth, Diadema, São Paulo, Brazil). The reading 
was performed on a microplate spectrophotometer (Versamax, Molecular Devices, USA) using ethyl alcohol as white $(\lambda 530$ and $590 \mathrm{~nm})[5]$.

The cfu / $\mathrm{mL}$ log data and optical densities were analyzed applying the one-way ANOVA (Graphpad Prism 5.0 ) test, considering a significance level of $5 \%$.

\section{RESULTS}

The minimum inhibitory concentration of the $M$. recutita extract for $C$. albicans and E. cloacae was 83 and $100 \mathrm{mg} / \mathrm{mL}$ in the planktonic phase, respectively. Both were inhibited by chlorhexidine $0.12 \%$ (Periogard $\AA$ $0.12 \%)$

Considering the biofilm study, there was a percentage reduction in the number of $\mathrm{cfu} / \mathrm{mL}$ of $\mathrm{C}$. albicans for all concentrations of $M$. recutita extract and chlorhexidine $0.12 \%$ (Md 72.4 to 99.6\%). However, when comparing the efficacy between the concentrations, although there was a decrease in the log of cfu / $\mathrm{mL}$ with the increase in extract concentration, this difference was not significant, even when compared to chlorhexidine $0.12 \%(p=0.565$, Figure 1$)$.

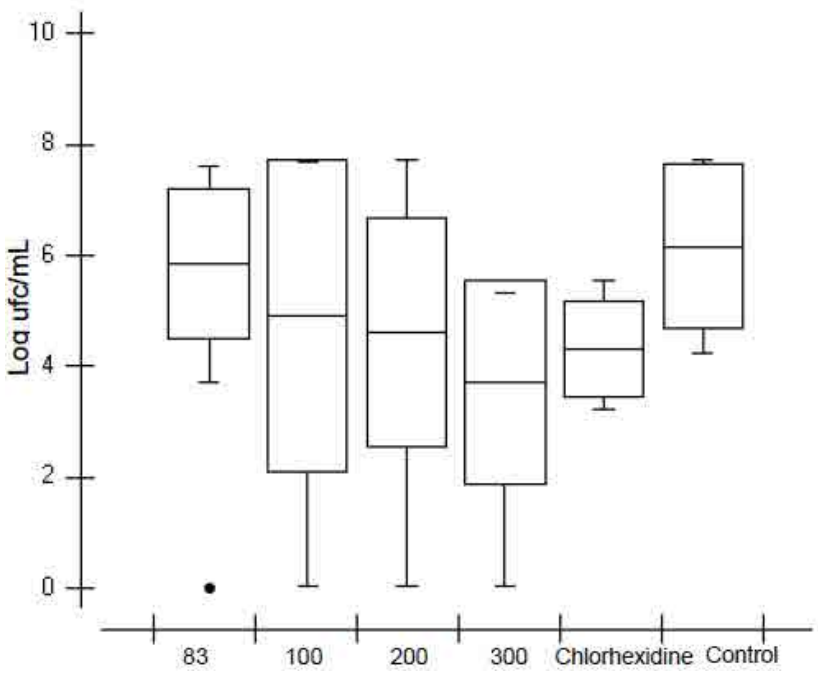

Figure 1. Mean and standard deviation of cfu $\mathrm{log} / \mathrm{ml}$ of untreated Candida albicans biofilm (control) or treated for five minutes with Matricaria recutita extract at $83,100,200$ and $300 \mathrm{mg} / \mathrm{ml}$ and chlorhexidine $0.12 \%$ (ANOVA, $p=$ $0.565)$.

When comparing the optical densities obtained in the cell viability test in $C$. albicans biofilm, there was no significant difference $(p=0.8094)$ in the amount of viable DNA between the control and the tested concentrations of $M$. recutita extract $(83,100,200,300 \mathrm{mg} / \mathrm{mL})$ and chlorhexidine $0.12 \%$ (Table 1 ).

For the $E$. cloacae biofilm, the $M$. recutita extract at $300 \mathrm{mg} / \mathrm{mL}$ significantly reduced $(p<0.01)$ the number of $\mathrm{cfu} / \mathrm{mL}$, when compared to the control, with results similar to chlorhexidine $0.12 \%$, while the extracts at 100 and 200 $\mathrm{mg} / \mathrm{mL}$ did not have the same effectiveness (Figure 2).

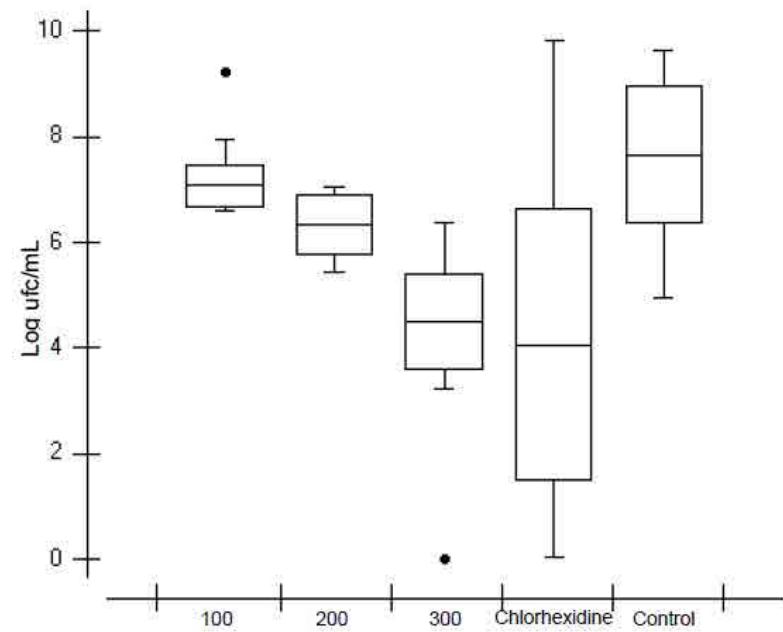

Figure 2. Mean and standard deviation of log cfu/ml of untreated Enterobacter cloacae biofilm (control) or treated for five minutes with Matricaria recutita extract at 100, 200 and $300 \mathrm{mg} / \mathrm{ml}$ and chlorhexidine $0.12 \%$ (ANOVA, p<0.01).

For the $E$. cloacae cell viability test, the analysis of optical densities showed that $M$. recutita extract in all the tested concentrations $(100,200$ and $300 \mathrm{mg} / \mathrm{mL})$, as well as chlorhexidine $12 \%$, significantly reduced the biofilm viable DNA ( $p<0.05)$ when compared to the control. There was no difference between the extract concentrations and between each concentration and the chlorhexidine $0.12 \%$ in the reduction of viable DNA (Table 2).

Table 2. Optical densities for the cell viability test of Enterobacter cloacae in untreated biofilm (control) and treated with Matricaria recutita extract $(100,200$ and $300 \mathrm{mg} / \mathrm{mL}$ ) and chlorhexidine $0.12 \%$.

\begin{tabular}{|c|c|c|c|c|}
\hline \multicolumn{3}{|c|}{ Matricaria recutita Extract $(\mathrm{mg} / \mathrm{mL})$} & \multirow{2}{*}{$\begin{array}{l}\text { Chlorhexidine } \\
0.12 \%\end{array}$} & \multirow{2}{*}{ Control } \\
\hline $10 \%$ & $20 \%$ & $30 \%$ & & \\
\hline 0.098 & 0.117 & 0.121 & 0.746 & 1.207 \\
\hline 0.11 & 0.14 & 0.095 & 0.135 & 0.69 \\
\hline 0.336 & 0.177 & 0.118 & 0.168 & 0.479 \\
\hline 0.12 & 0.213 & 0.139 & 0.159 & 0.921 \\
\hline 0.163 & 0.325 & 0.119 & 0.336 & 0.419 \\
\hline 0.122 & 0.088 & 0.325 & 0.189 & 0.221 \\
\hline 0.064 & 0.071 & 0.285 & 0.166 & 0.053 \\
\hline 0.062 & 0.066 & 0.078 & 0.042 & 0.055 \\
\hline 0.127 & 0.078 & 0.056 & 0.035 & 0.145 \\
\hline 0.066 & 0.049 & 0.055 & 0.093 & 0.159 \\
\hline 0.072 & 0.085 & 0.101 & 0.061 & 0.101 \\
\hline 0.061 & 0.182 & 0.105 & 0.034 & 0.121 \\
\hline
\end{tabular}




\section{DISCUSSION}

The most common and effective strategy to prevent caries, gingivitis, periodontitis and other oral conditions related to biofilm accumulation is its mechanical removal from dental surfaces, restorations or dental prostheses by regular brushing [18]. However, it is often necessary to use mouthwashes with antimicrobial substances to assist in the biofilm control.

The search for a drug capable of reducing microorganisms, which can be pathogenic in various situations in the oral cavity, not causing side effects, especially when indicated for prolonged use, is appropriate and assists in obtaining reliable alternatives for medical/ dental use.

In this research study, the chlorhexidine digluconate $0.12 \%$ (Periogard $\AA$ ) was used as inhibitory control because it is considered a gold standard for oral cavity antisepsis. It has an antibiofilm action and can cause immediate reduction in $90 \%$ of the microorganisms. Its effect can remain from 30 seconds to 1 hour after mouthwashing, with a residual effect of until 7 hours [19]. However, despite its proven antimicrobial efficacy, its prolonged use causes alterations in the color of dental elements, restorations, prostheses, loss of taste, unpleasant residual taste in the mouth and, in a smaller number of cases, soft tissue burns, xerostomia, mucosa ulcerations, reversible swellings on the lips and parotid glands, scaly lesions, urticaria, dyspnea and anaphylactic shock [11]. Thus, the search for substances capable of inhibiting biofilms with fewer side effects, or rather without them, is justified. Among the phytotherapic agents most studied for dental use based on their antimicrobial, anti-inflammatory, healing and analgesic characteristics, clove, pomegranate, mallow, cat's claw and chamomile [20] stands out, the latter being the target of the present study. The matricaria recutita (chamomile) was the one chosen for this study due of its great consumption by the population as tea. It delivers a pleasant flavor, which would facilitate its use as a mouthwash and would still have little or no side effects when used for long periods. The goal of this research study was to verify the antibiofilm action of a chamomile formulation, in this case, the hydroalcoholic extract, as it has components with antimicrobial properties, such as the cis-trans-spiroethers, and coumarins, such as the herniarine and umbelliferone [21]. A concern was also to investigate published studies considering microorganisms in the planktonic phase presenting satisfactory results $[22,23]$, low cost and with potential to be used as a mouthwash. In the present study, to determine the minimum concentration of chamomile extract to be used in $C$. albicans and $E$. cloacae biofilms, as well as the effectiveness of the chlorhexidine formulation $0.12 \%$ (Periogard $囚$ ), the broth microdilution test for these microorganisms when in the planktonic phase was carried out, which were respectively inhibited at 83 and $100 \mathrm{mg} / \mathrm{mL}$ and also by $0.12 \%$ chlorhexidine. In a disk-diffusion study with $25 \%$ (250 mg / mL) aqueous chamomile extract, Rahman and Chandra [24] reported a $24.16 \mathrm{~mm}$ inhibition halo for Candida albicans in planktonic phase when compared to $33.26 \mathrm{~mm}$ halo for chlorhexidine $2 \%$. For E. cloacae, the inhibitory and bactericidal concentration were $10 \mu \mathrm{g} / \mathrm{mL}$ of chamomile essential oil, using microdilution in broth [25]. Both studies applied a chamomile formulation or a methodology different from those applied in this study, which could justify the difference of the results found.

Both C. albicans and E. cloacae were the microorganisms chosen for the tests due to their importance in oral diseases $[3,9,10]$ ability to form biofilm $[26,27]$, resistance $[8,27]$ and the few studies related to the inhibitory activity of the hydroalcoholic extracts of chamomile when in biofilm. This work prioritized biofilm tests, since in this condition such microorganisms become more resistant to aggressions, increasing their capacity to install possible pathologies in the host. The efficacy of the hydroalcoholic extract of chamomile compared to chlorhexidine $0.12 \%$ was evaluated by two methods: colony-forming unit counts and Violet Crystal (VC).

The counting of colony forming units is a classic and reliable method, however it is very laborious, requiring culture medium and incubation time, besides counting and calculation to obtain the final result.

The quantification of biomass or cell density of viable cells with violet crystal has been a technique used in works with in vitro biofilm formation, being considered an sensitive indirect technique to demonstrate the formation of the same [28], besides being simple, economical and quick to achieve results.

According to the results achieved, there was a correlation between the cfu/mL count and the viable DNA density by the crystal violet technique. Considering the C. albicans biofilms, there was no significant reduction in the number of cfu/mL for all concentrations of the chamomile extract and chlorhexidine $0.12 \%$ in relation to the control, the same as with the crystal violet technique. In the $E$. cloacae biofilm, there was a significant reduction 
in the number of cfu/mL only for the extract at $300 \mathrm{mg} /$ $\mathrm{mL}$ and chlorhexidine $0.12 \%$, whereas for the crystal violet technique, there was reduction with all the concentrations of the extract. Non-correlation in all assays may be due to the method of fixation applied, unlike other experiments that found high correlation. In the present study, fixation was performed with $10 \%$ formaldehyde, following the methodology described by Oliveira et al. [5] Freitas et al. [28] used thermal fixation ( $60^{\circ} \mathrm{C}$ for 60 minutes), based on Stepanovi区 [29] who reports that thermal fixation is the best method, but, also, gives the option of fixation using methanol for twenty minutes, followed by discarding and drying overnight at room temperature with the plate inverted.

There was a decrease in the number of cfu/ $\mathrm{mL}$ for the C. albicans biofilms, with an increase in the concentration of the chamomile extract. Although the maximum reduction obtained with the extract at $300 \mathrm{mg} /$ $\mathrm{mL}$ was similar to that caused by chlorhexidine $0.12 \%$, there was no statistical difference with the control (untreated biofilm). The similarity with the reduction caused by chlorhexidine $0.12 \%$ was also obtained by the extract of chamomile $300 \mathrm{mg} / \mathrm{mL}$ for the biofilm of E. cloacae. However, this reduction was significant in relation to the control, demonstrating a better inhibitory action of both chamomile extract $300 \mathrm{mg} / \mathrm{mL}$ and chlorhexidine $0.12 \%$ for the E. cloacae biofilm.

In the reviewed literature, no experiment was found to test the action of chamomile with Candida

\section{REFERENCE}

1. Mavor AL, Thewes S, Hube B. Systemic fungal infections caused by Candida species: epidemiology, infection process and virulence attributes. Curr Drug Targets. 2005;6(8):863-874. doi: $10.2174 / 138945005774912735$

2. Conti HR, Gaffen SL. IL-17-mediated immunity to the opportunistic fungal pathogen Candida albicans. J Immunol. 2015 Aug;195(3): 780-8. doi: 10.4049/jimmunol.1500909

3. Gulati M, Nobile CJ. Candida albicans biofilms: development, regulation, and molecular mechanisms. Microbes Infect. 2016;18(5):310-321. doi: 10.1016/j.micinf.2016.01.002

4. Nobile CJ, Johnson AD. Candida albicans biofilms and human disease. Annu Rev Microbiol. 2015;69:71-92. doi: 10.1146/ annurev-micro-091014-104330

5. Oliveira VM, Santos SS, Silva $C R$, Jorge $A O$, Leão $M V$. Lactobacillus is able to alter the virulence and the sensitivity profile of Candida albicans. J Appl Microbiol. 2016;121(6):17371744. doi: 10.1111/jam.13289 or Enterobacter species, or even another species of enterobacterium in biofilm. However, Agarwal et al. [30] applying different methodology from this work, among the essential oils tested against Candida species, the chamomile was not among the most effective ones.

Therefore, results achieved in this research study embase new knowledge, as they demonstrate the inhibitory action of the hydroalcoholic extract of chamomile on $C$. albicans and E. cloacae. And, additional literature data considering its effective action in other oral microorganisms in biofilm, brings the possibility of performing further tests, aiming at its use as an oral antiseptic, even as an alternative to the use of chlorhexidine digluconate $0.12 \%$.

\section{CONCLUSION}

The $M$. recutita extract $300 \mathrm{mg} / \mathrm{mL}$ significantly reduced the $E$. cloacae biofilm, but, not the $C$. albicans biofilm, both with a similar result to chlorhexidine $0.12 \%$ $\left(\right.$ Periogar $\left.{ }^{\circledR}\right)$

\section{Collaborators}

MA PEQUENO, implementation of methodology and writing. MR SILVESTRE, implementation of methodology and writing. I AMÊNDOLA, implementation of methodology and statistics. CRG SILVA and MVP LEÃO, outline of the methodology. SSF SANTOS, outline of the methodology and Orientation

6. Komiyama EY, Santos SS, Jorge AO, Martins CAP, Cristiane YK Produção de exoenzimas por amostras de Candida albicans isoladas de pacientes com periodontite crônica e indivíduoscontrole. Rev Odontol Univ São Paulo. 2007;19(3):288-92.

7. Mezzatesta ML, Gona F, Stefani S. Enterobacter cloacae complex: clinical impact and emerging antibiotic resistance. Future Microbiol. 2012;7(7):887-902. doi: 10.2217/fmb.12.61

8. Van Hoek AH, Schouls L, Van Santen MG, Florijn A, De Greeff SC, Van Duijkeren E. Molecular characteristics of extendedspectrum cephalosporin-resistant Enterobacteriaceae from humans in the community. PLoS One. 2015;6(10):1-12. doi: 10.1371/journal.pone.0129085

9. Santos SS, Jussara C S, Clélia AP, Jorge AOC. Prevalência e sensibilidade in vitro de Enterobacteriaceae e Pseudomonas isoladas da cavidade bucal e bolsa periodontal de pacientes com periodontite crônica. PGRO-Pós-Grad Rev Odontol. 2002;5(2):74-83.

10. Conti S, Santos SS, Koga-ito CY, Jorge AOC. Enterobacteriaceae and Pseudomonadaceae on the dorsum of the human tongue. J Appl Oral Sci. 2009 Set-Oct;5(17): 375-380. doi: 10.1590/ S1678-77572009000500005 
11. Pegoraro J, Silvestri L, Cara G, Stefenon L, Mozzini CB. Efeitos adversos do gluconato de clorexidina à 0,12\%. J Oral Invest. $2014 \mathrm{Nov} ; 3(1): 33-37$.

12. Bettega PVC, Czlusniak GR, Piva R, Namba EL, Ribas CR, Grégio AMT, et al. Fitoterapia: dos canteiros ao balcão da farmácia. Arch Oral Res. 2011 Jan-Apr;7(1):89-97.

13. Brasil. Ministério da Saúde. Secretaria de Ciência, Tecnologia e Insumos Estratégicos. Departamento de Assistência Farmacêutica. Política nacional de plantas medicinais e fitoterápicos. Brasília: Ministério da Saúde; 2006 [citado 2017 Set 15]. Disponível em: <http://bvsms.saude.gov.br/bvs/ publicacoes/politica_nacional_fitoterapicos.pdf>.

14. Francisco K. Fitoterapia: uma opção para o tratamento odontológico. Rev Saúde - UnG. 2009;4(1):18-24.

15. Batista AL, Lins RD, De Souza CR, Do Nascimento BD, Moura BN, Alves CFJ. Clinical efficacy analysis of the mouth rinsing with pomegranate and chamomile plant extracts in the gingival bleeding reduction. Complement Ther Clin Pract. 2013 Set; 20(1): 93-98. doi: 10.1016/j.ctcp.2013.08.002

16. Clinical and Laboratory Standards Institute. Methods for dilution antimicrobial susceptibility tests for bacteria that grow aerobically approved standard. Wayne: Clinical and Laboratory Standards Institute; 2003.

17. Herigstad $B$, Hamilton $M$, Heersink J. How to optimize the drop plate method for enumerating bactéria. J Microbiol Methods. 2001;44(2):121-129. doi: 10.1016/S0167-7012(00)00241-4

18. Arweiler NB, Netuschil L. The oral microbiota. Adv Exp Med Biol. 2016;902:45-60. doi: 10.1007/978-3-319-31248-4_4

19. Nogueira MN, Ferreira MC, Fontana A, Bedran TBL, Spolidorio DMP. Avaliação comparativa in vivo da eficácia do óleo de melaleuca, clorexidina e listerine sobre Streptococcus mutans e microrganismos totais na saliva. Pesq Bras Odontoped Clin Integr. 2013;13(4):343-349.

20. Chinsembu KC. Plants and other natural products used in the management of oral infections and improvement of oral health. Acta Trop. 2016;154:6-18. doi: 10.1016/j. actatropica.2015.10.019

21. Móricz AM, Szarka S, Ott PG, Héthelyi EB, Szoke E, Tyihák E. Separation and identification of antibacterial chamomile components using OPLC, bioautography and GC-MS. Med Chem. 2012;8(1):85-94. doi: 10.2174/157340612799278487
22. Carvalho AF, Silva DM, Silva TRC, Scarcelli E, Manhani MR Avaliação da atividade antibacteriana de extratos etanóico e de ciclohexano a partir das flores de camomila (Matricaria chamomilla L.). Rev Bras PI Med. 2014 Mar;16(3):521-526.

23. Munir N, lqbal AS, Altaf I, Bashir R, Sharif, N, Saleem F, et al Evaluation of antioxidant and antimicrobial potential of two endangered plants species Atroppa Belladonna and Matricaria chamomilla. Afr J Tradit Complement Med. 2014;11(5):111117

24. Rahman $\mathrm{H}$, Chandra A. Microbiologic evaluation of matricaria and chlorhexidine against E. faecalis and C. albicans. Indian J Dent. 2015;6(2):60-64. doi: 10.4103/0975-962X.155876

25. Sokovic M, Glamočlija J, Marin PD, Brkić D, Van Griensven LJ. Antibacterial effects of the essential oils of commonly consumed medicinal herbs using an in vitro model. Molecules. 2010;15(27):532-546. doi: 10.3390/molecules15117532

26. Soll DR, Daniels KJ. Plasticity of Candida albicans Biofilms. Microbiol Mol Biol Rev. 2016;80(3):565-95. doi: 10.1128/ MMBR.00068-15

27. Guérin F, Lallementa C, Isnarda C, Dhalluina A, Cattoira V Giarda JC. Landscape of resistance-nodulation-cell division (RND)-type efflux pumps in Enterobacter cloacae Complex. Antimicrob Agents Chemother. 2016:60(4):2373-2382. doi: 10.1128/AAC.02840-15

28. Freitas VR, van Der Sand ST, Simonetti AB. Formação in vitro de biofilme por Pseudomonas aeruginosa e Staphylococcus aureus na superfície de canetas odontológicas de alta rotação. Rev Odontol UNESP. 2010;39(4):193-200.

29. Stepanović S, Vuković D, Hola V, Di Bonaventura G, Djukić S, Cirković l, et al. Quantification of biofilm in microtiter plates: overview of testing conditions and practical recommendations for assessment of biofilm production by staphylococci. APMIS. 2007;115(8): 891-9.

30. Agarwal V, Lal P, Pruthi VC. Prevention of Candida albicans biofilm by plant oils. Mycopathologia. 2008;165(1):13-9.

Received on: 17/5/2017

Final version resubmitted on: 14/7/2017

Approved on: 21/9/2017 